Volume 4 Nomor 1, Juni 2017, Hlm 88-99

Akses Online :

http:// jurnal.lp2msasbabel.ac.id

Dipublikasikan oleh :

Fakultas Tarbiyah IAIN Syaikh Abdurrahman Siddik Bangka Belitung

Info Artikel:

Diterima: 09/03/2017_Direvisi: 20/03/2017_ Dipublikasikan: 01/06/2017

\title{
KEMAMPUAN BERPIDATO DENGAN METODE MEMORITER MAHASISWA SEMESTER I TAHUN AKADEMIK 2016/2017 SEKOLAH TINGGI AGAMA ISLAM NEGERI SYAIKH ABDURRAHMAN SIDDIK BANGKA BELITUNG
}

\section{EVA HARISTA ${ }^{1}$ \\ IAIN Syaikh Abdurrahman Siddik Bangka Belitung}

\begin{abstract}
ABSTRAK
Penelitian ini bertujuan untuk mengetahui kemampuan berpidato dengan menggunakan metode momoriter yang ditinjau dari aspek kebahasaaan dan aspek nonkebahasaaan. Penelitian ini menggunakan metode penelitian deskriptif kuantitatif. Pengumpulan data menggunakan teknik tes dengan sampel sebanyak 97 mahasiswa. Hasil penelitian menunjukkan bahwa kemampuan berpidato mahasiswa dengan metode memoriter ditinjau dari aspek kebahasaan berkategori baik dengan nilai rata-rata 78,8\% dan ditinjau dari aspek nonkebahasaan juga berkategori baik dengan nilai rata-rata 82,6\%. Maka secara keseluruhan, hasil penelitian kemampuan berpidato dengan metode memoriter mahasiswa Semester I Tahun Akademik 2016/2017 Sekolah Tinggi Agama Islam Negeri Syaikh Abdurrahman Siddik Bangka Belitung berkategori baik dengan nilai rata-rata $80,7 \%$.
\end{abstract}

Kata Kunci: Kemampuan, Pidato, Memoriter, Mahasiswa.

\begin{abstract}
This study aims to determine the ability of speech by using momoriter viewed from the language aspect and the nonlanguage aspect. This research uses descriptive quantitative research methods. Collecting data using the testing techniques with a sample of 97 students. The results showed that the ability of the student speech at memoriter methods in terms of both aspects of language category with an average value of $78.8 \%$ and in terms of aspects nonkebahasaan also categorized well with the average value of $82.6 \%$. So overall, the results of research capabilities addressed by the method memoriter students Semester, Academic Year 2016/2017
\end{abstract}

\footnotetext{
${ }^{1}$ Dosen Sekolah Tinggi Agama Islam Negeri Syaikh Abdurrahman Siddik Bangka Belitung.
} 


\section{A. PENDAHULUAN}

Mata kuliah Bahasa Indonesia sebagai Mata Kuliah Umum (MKU) juga merupakan mata kuliah Pengembangan Kepribadian (MPK). Undang-undang Nomor 2 Tahun 1989 tentang Sistem Pendidikan Nasional dan ditegaskan kembali pada Undangundang Nomor 20 Tahun 2003 yang menyatakan bahwa mata kuliah bahasa Indonesia merupakan mata kuliah yang wajib diberikan di semua jenjang pendidikan dan jalur pendidikan.

Pada jenjang Perguruan Tinggi, mata kuliah bahasa Indonesia didapatkan pada Semester I. Mata kuliah ini merupakan mata kuliah yang didesain agar mahasiswa mempunyai kompetensi dan keterampilan menggunakan bahasa Indonesia yang baik dan benar, baik dalam ranah membaca, berbicara, menyimak, dan menulis karya ilmiah. Salah satu kompetensi yang harus dikuasai mahasiswa adalah berbicara menggunakan bahasa Indonesia dengan baik dan benar. Tarigan berpendapat bahwa berbicara adalah kemampuan mengucapkan bunyi-bunyi artikulasi atau kata-kata untuk mengekspresikan, menyatakan, menyampaikan pikiran, gagasan, dan perasaan. ${ }^{2}$ Untuk itu, dalam silabus mata kuliah bahasa Indonesia terdapat materi tentang pidato. Di dalam materi berpidato, mahasiswa dilatih untuk dapat berbicara menggunakan bahasa Indonesia dengan baik dan benar.

Menurut Jalaluddin, pidato adalah komunikasi tatap muka yang bersifat dua arah. Pembicara harus memperhatikan lawan bicaranya. Hal ini karena pembicara lebih banyak mendominasi pembicaraan. ${ }^{3}$ Pidato adalah sebuah kegiatan berbicara di depan umum atau bisa dikatakan sebagai public speaking. ${ }^{4}$ Dalam teori public speaking, seorang pembicara harus mempunyai keterampilan dalam memikat hati lawan bicaranya, salah satunya dengan menggunakan bahasa yang baik, dan menguasai teknik-teknik dalam berbicara.

Hal ini sejalan dengan pendapat Iskandarwassid dan Sunendar yang menjelaskan bahwa keterampilan pidato merupakan kegiatan berbicara di depan umum dengan memperhatikan aspek ilmu, seni, dan keterampilan. Aspek ilmu mencakup penguasaan

\footnotetext{
2008, hlm. 16.

${ }^{3}$ Rakhmat Jalaluddin, Retorika Modern (Pendekatan Praktis), Bandung: Remaja Rosdakarya, 2011, hlm. 78

${ }^{4}$ Putri Pandan Wangi, Bukan Pidato Biasa, Klaten: One Books, 2010, hlm. 11
}

2 Henry Guntur Tarigan, Berbicara Sebagai Suatu Keterampilan Berbahasa, Bandung: Angkasa, 
materi yang akan dipidatokan. Aspek seni menyangkut keindahan menampilkan pidatonya Sementara itu, aspek keterampilan menyangkut caranya berpidato. ${ }^{5}$

Senanda dengan pendapat tersebut, Arifin dan Tasai menyatakan bahwa berpidato memerlukan dan mementingkan ekspresi gagasan pernalaran dengan menggunakan bahasa lisan yang didukung oleh aspek nonbahasa, seperti ekspresi wajah, kontak pandang, dan intonasi suara. ${ }^{6}$

Ada tujuh macam pidato berdasarkan dalam rangka apa pidato itu diadakan yaitu pidato informatif/instruktif, pidato persuasif, pidato argumentatif, pidato deskriptif, pidato rekreatif, pidato edukatif, dan pidato entertain. ${ }^{7}$

Jalaluddin Rahmat menjelaskan terdapat empat jenis pidato yaitu sebagai berikut: ${ }^{8}$

1. Impromtu

Pidato ini biasanya disampaikan pada acara resmi (pesta dan lain-lain). Pidato impromtu disampaikan tanpa persiapan dan tidak menggunakan naskah.

2. Manuskrip

Pidato ini biasanya menggunakan naskah. Juru pidato membacakan naskah dari awal sampai akhir.

3. Memoriter

Pidato jenis ini biasanya juga ditulis kemudian dalam penyampaian diingat kata demi kata. Langkah-langkah persiapan yang diperlukan lebih banyak terarah kepada usaha mengingat pesan pidato, di samping persiapan naskah yang baik.

4. Ekstemporan

Pidato ini yang dikatakan pidato paling baik (dari sudut teori komunikasi). Pidato ekstempore sering digunakan oleh juru pidato/pembicara yang mahir. Dalam pembicaraan juru pidato tidak menggunakan naskah (teks). Oleh karena itu, langkahlangkah persiapan harus dilakukan dengan baik dan matang.

Keempat jenis pidato ini (impromtu, manuskrip, memotiter, ekstemporan) juga merupakan metode-metode dalam berpidato. Pada penelitian ini, sengaja dipilih pidato jenis memoriter, karena sampel penelitian adalah mahasiswa baru tahun Akademik 2016/2017. Pidato jenis ini biasanya sering dilakukan dan diterapkan untuk seorang pemula. Pidato jenis

5 Iskandarwassid dan Dadang Sunendar, Strategi Pembelajaran Bahasa, Bandung: Remaja Rosdakarya, 2008, hlm. 9.

${ }^{6}$ E. Z. Arifin, Tasai, S.A., Cermat Berbahasa Indonesia, Jakarta: Akademi Pressindo, 2008, hlm. 228.

${ }^{7}$ Putra Bahar, Seni Pidato 7 Langkah Sukses Membawakan Pidato, Tangerang: Sunshine Book, 2010, hlm. 21

${ }^{8}$ Anwar G.entasri, Teknik dan Seni Berpidato, Jakarta: Rineka Cipta, 2003, hlm. 34 
memoriter ini dapat menjadi latihan yang baik untuk seorang pemula dalam berpidato. Alasan lain adalah agar mahasiswa dapat lebih siap secara fisik dan mental dalam menyampaikan pidato, karena sebelum tampil, mereka diberikan waktu yang cukup lama untuk mempersiapkan diri dengan membuat teks/naskah pidato sesuai dengan tema yang akan disampaikan dan melakukan latihan sedemikian rupa agar mendapatkan hasil yang maksimal.

Akan tetapi, pidato jenis memoriter ini terdapat kelemahan yaitu jika juru pidato lupa dengan bagian teks/naskah yang akan disampaikan, biasanya pidato yang disampaikan menjadi tidak lancar, bahkan bisa menyebabkan juru pidato kehilangan kata-kata. Untuk itu, dalam menyikapi pidato ini, juru pidato tidak bisa hanya mengandalkan hafalan teks/naskah saja, melainkan harus mempunyai pengetahuan lebih tentang tema yang akan disampaikan. Hal ini tentu saja membutuhkan pernalaran yang baik dalam merangkai kata-kata dan kalimat demi kalimat untuk menggantikan teks/naskah yang lupa.

Kelemahan lain dalam pidato jenis memoriter ini adalah sering kali juru pidato tidak fokus dalam memberikan perhatian kepada lawan bicaranya. Hal ini disebabkan karena juru pidato lebih fokus dalam mengingat teks/naskah yang akan dia sampaikan. Hal ini tentunya akan menyebabkan hubungan antara juru bicara dengan lawan bicaranya menjadi kurang baik, sehingga tidak heran terkadang pesan yang disampaikan oleh juru bicara tidak sampai kepada lawan bicaranya.

Untuk menyikapi hal tersebut, agar juru pidato lebih memberikan perhatian kepada lawan bicaranya, hendaknya juru pidato melakukan latihan dan persiapan yang matang tentang materi/teks/naskah yang akan disampaikan. Jika merasa belum menguasai sepenuhnya teks tersebut, maka perlu diulang kembali sehingga benar-benar menguasai materi. Selain itu juru pidato perlu banyak pengetahuan yang bisa diperoleh dengan membaca tentang materi yang akan disampaikan. Maka, ketika juru bicara menguasai materi yang disampaikannya, tentu saja perhatian kepada lawan bicaranya akan menajdi fokus dan pesan yang ingin disampaikan dapat diterima dengan baik.

Berpidato sejatinya adalah kemampuan berbicara. Secara umum aspek yang dapat dinilai di dalam ujian berbicara menurut Safari di antaranya sebagai berikut: ${ }^{9}$

a. Aspek kebahasaaan, di antaranya:

1) Ketepatan pengucapan/pelafalan: vokal, konsonan, intonasi, dan tekanan.

2) Ketepatan penempatan tekanan kata/ungkapan.

${ }^{9}$ Safari, Pengujian dan Penilaian Bahasa dan Sastra Indonesia. Jakarta: PT Kartanegara, 1997, hlm. 
3) Ketepatan penggunaan: nada/irama, pilihan kata, ungkapan, istilah, variasi kata, tata bentukan, struktur kalimat, ragam kalimat, majas.

b. Aspek pengungkapan, di antaranya:

1) Kelancaran (tidak banyak mengulang-ulang kata yang sama).

2) Tempo bicara (lambat, sedang, cepat, terlalu cepat).

3) Menirukan/mengkopi kebiasaan pembicara lain atau tidak.

4) Kenyaringan suara.

5) Gerak-gerik dan mimik.

6) Nada (tidak monoton).

7) Fasih, jelas, sederhana, dan mudah dipahami.

8) Terampil tidaknya untuk mengatasi kesulitan bila kehilangan jalan pikiran.

9) Gaya menyampaikan/berbicara.

c. Aspek penampilan dan sikap, di antaranya:

1) Keberanian dan semangat, menghormati, menghargai, percaya diri, memikat lawan bicara, akrab, memberi dorongan/motivasi.

2) Pandangan mata

3) Terkontrol tidaknya gerak-gerik anggota badan.

4) Posisi tangan, anggota badan (seperti: menggaruk-garuk telinga, kumis, jenggot, menggigit bibir, memainkan kancing baju).

5) Rasa takut, cemas, kurang konsentrasi, tegang, gugup, hati-hati, emosi.

6) Ketepatan waktu yang diberikan.

7) Keterbukaan/kejujuran.

8) Dapat merasakan reaksi pendengar/lawan bicara.

d. Aspek materi yang dibicarakan

1) Tingkat penguasaan materi/topik yang dibicarakan.

2) Tingkat penguasaan bahan pendukung.

3) Kesesuaian/relevansi dengan topik yang dibicarakan.

4) Tingkat penalaran (berpikir sistematis, konsisten, logis, tepat, dan benar).

5) Mampu menangkap maksud dan arah pembicaraan.

Roekhan dan Martutik memaparkan bahwa dalam penilaian kemampuan berbicara dapat dilakukan secara aspektual atau secara komprehensif. Penilaian aspektual yang dimaksud adalah penilaian kemampuan berbicara yang difokuskan pada aspek-aspek tertentu, 
Surnal TARBAWY

Jurnal Pendidikan Islam
Volume 4 Nomor 1, Juni 2017

Akses Online: http:// jurnal.lp2msasbabel.ac.id

dan penilaian komprehensif merupakan penilaian yang difokuskan pada keseluruhan kemampuan berbicara. ${ }^{10}$

Lebih lanjut Roekhan dan Martutik mengemukakan penilaian aspektual dapat dibedakan menjadi dua yaitu penilaian aspektual individual dan penilaian aspektual kelompok. Secara umum dalam penilaian aspektual individual terdiri dari dua aspek yaitu aspek kebahasaan dan aspek nonkebahasaan. Aspek kebahasaan yang dinilai berupa (1) tekanan, (2) ucapan, (3) nada dan irama, (4) persendian, (5) kosa kata/ungkapan atau diksi, (6) struktur kalimat yang digunakan, sedangkan aspek nonkebahasaan yang dinilai berupa (1) kelancaran, (2) pengungkapan materi, (3) keberanian, (4) keramahan, (5) ketertiban, (6) semangat, (7) sikap, (8) perhatian. Sedangkan aspek-aspek dalam penilaian aspektual kelompok yaitu berupa: (1) pemerataan kesempatan berbicara, (2) keterarahan pembicaraan, (3) kejelasan bahasa yang digunakan, (4) kebakuan bahasa yang digunakan, (5) penalaran dalam berbicara, (6) kemampuan mengemukakan ide baru, dan (7) kemampuan menarik kesimpulan. $^{11}$

Sementara itu, penilaian berbicara komprehensif dimaksudkan untuk mengetahui kemampuan testi dalam berbicara secara menyeluruh, tidak sepotong-sepotong. Penilaian komprehensif dapat dibedakan menjadi dua macam, yaitu: penilaian komprehensif individual dan penilaian komprehensif kelompok. Penilaian berbicara komprehensif tidak dilakukan per aspek, tetapi dilakukan secara utuh. Penilaian ini dilakukan dengan cara mendasarkan diri pada mudah tidaknya dipahami isi pembicaraan, menarik tidaknya pembicaraan, serta lancar tidaknya pembicaraan. ${ }^{12}$

Senada dengan penjelasan di atas, Arsjad dan Mukti juga memaparkan hal yang sama tentang faktor-faktor yang dapat menunjang keefektifan berpidato, yaitu faktor kebahasaan dan faktor nonkebahasaan. Faktor kebahasaan meliputi (1) ketepatan ucapan, (2) penempatan tekanan, nada, sendi, dan durasi yang sesuai, (3) pilihan kata/diksi, (4) ketepatan sasaran pembicaraan, sedangkan faktor nonkebahasaan meliputi (1) sikap yang wajar, tenang, dan tidak kaku, (2) pandangan harus diarahkan kepada lawan bicara, (3) kesediaan menghargai orang lain, (4) gerak-gerik dan mimik yang tepat, (5) kenyaringan suara, (6) kelancaran, (7) relevansi/penalaran, (8) penguasaan topik. ${ }^{13}$

${ }^{10}$ Roekhan dan Martutik, Evaluasi Pengajaran Bahasa Indonesia, Malang: YA3 Malang, 1991, hlm.

11 Ibid.

${ }^{12}$ Ibid., hlm. 59

13 M.G. Arsjad dan Mukti, Pembinaan Kemampuan Berbicara Bahasa Indonesia, Jakarta: Bina Aksara, 1988, hlm. 17 


\section{B. METODE PENELITIAN}

Metode yang digunakan dalam penelitian ini adalah metode deskriptif kuantitatif. Sugiono menjelaskan bahwa metode deskriptif kuantitatif adalah metode penelitian yang berlandaskan pada filsafat positifisme, digunakan untuk meneliti pada populasi dan sampel tertentu, pengumpulan data menggunakan instrumen penelitian, analisis data bersifat kuantitatif/statistik, dengan tujuan untuk menguji hipotesis yang telah ditetapkan. ${ }^{14}$

Penelitian ini dilakukan di Sekolah Tinggi Agama Islam Negeri Syaikh Abdurrahman Siddik Bangka Belitung. Populasi penelitian ini yaitu seluruh mahasiswa Semester I Tahun Akademik 2016/2017, yang berjumlah 485 mahasiswa. Dari jumlah populasi tersebut diambil sampel sebanyak 20\% dari jumlah populasi yaitu sebanyak 97 mahasiswa, yang terdiri dari tiga Jurusan yaitu Jurusan Tarbiyah, Jurusan Dakwah dan Komunikasi, dan Jurusan Syariah dan Ekonomi Islam. Dalam pengambilan sampel ini, peneliti menggunakan teknik proporsional random sampling. ${ }^{15}$

Peneliti mengambil data untuk penelitian ini yaitu pada saat mata kuliah Bahasa Indonesia berlangsung dengan materi praktik pidato, yaitu pada pertemuan ke 14 dan 15 . Materi praktik pidato memang sengaja dimasukan ke dalam silabus perkualiahan, karena mahasiswa dituntut mempunyai kompetensi atau kemampuan dalam membaca, menulis, dan berbicara.

Untuk mendapatkan data penelitian kemampuan berpidato dengan metode manuskrip, peneliti melakukan langkah-langkah sebagai berikut:

1) Peneliti menggunakan alat tes yaitu berupa unjuk kerja dengan menugaskan mahasiswa membuat teks/naskah pidato dengan tema bebas.

2) Peneliti memberikan waktu selama 1 minggu kepada mahasiswa untuk melakukan latihan berpidato sesuai dengan naskah yang mereka buat.

3) Peneliti menugaskan mahasiswa untuk berpidato dengan waktu kurang lebih 7 menit.

4) Peneliti melakukan penilaian langsung pada lembar rubrik penilaian yang telah disiapkan untuk menentukan tingkat kemampuan mahasiswa berpidato berdasarkan aspek kebahasaan dan aspek nonkebahasaaan.

${ }^{14}$ Sugiyono, Metode Penelitian Kuantitatif, Kualitatif, dan R\&D, Bandung: CV Alfabeta, 2009, hlm.

${ }^{15}$ Ibid., hlm. 82. 
Sturnal TARBAWY

Jurnal Pendidikan Islam
Volume 4 Nomor 1, Juni 2017 Akses Online: http:// jurnal.lp2msasbabel.ac.id

Adapun lembar penilaian pidato dengan sebagaimana tabel berikut:

Tabel 1. Rubrik Penilaian Kemampuan Berpidato

\begin{tabular}{|c|c|c|c|}
\hline No & Unsur Penilaian Aspektual & Skor & Nilai \\
\hline 1 & $\begin{array}{l}\text { Aspek Kebahasaan } \\
\text { 1.1 Ketepatan Ucapan } \\
\text { 1.2 Penempatan Tekanan } \\
\text { 1.3 Nada dan Irama } \\
\text { 1.4 Pilihan Kata atau Diksi } \\
\text { 1.5 Struktur Kalimat }\end{array}$ & $\begin{array}{l}5-10 \\
5-10 \\
5-10 \\
5-10 \\
5-10\end{array}$ & \\
\hline 2 & $\begin{array}{l}\text { Aspek Nonkebahasaan } \\
\text { 1.1 Kelancaran } \\
\text { 1.2 Penguasaan Materi } \\
\text { 1.3 Keberanian } \\
\text { 1.4 Sikap } \\
\text { 1.5 Perhatian }\end{array}$ & $\begin{array}{l}5-10 \\
5-10 \\
5-10 \\
5-10 \\
5-10\end{array}$ & \\
\hline & JUMLAH & $50-100$ & \\
\hline
\end{tabular}

Tabel 2. Persentase Kategori Kemampuan Berpidato

\begin{tabular}{|c|c|c|}
\hline No & Presentase & Kategori \\
\hline 1 & $>85$ & Sangat Baik \\
\hline 2 & $71-85$ & Baik \\
\hline 3 & $56-70$ & Sedang \\
\hline 4 & $<56$ & Kurang Baik \\
\hline
\end{tabular}


Jurnal TARBAWY

Jurnal Pendidikan Islam
Volume 4 Nomor 1, Juni 2017 Akses Online: http:// jurnal.lp2msasbabel.ac.id

\section{HASIL PENELITIAN DAN PEMBAHASAN}

Berdasarkan hasil penelitian yang telah dilakukan, dapat dilihat kemampuan berpidato mahasiswa Semester I Tahun Akademik 2016/2017 Sekolah Tinggi Agama Islam Negeri Syaikh Abdurrahman Siddik Bangka Belitung dari diagram berikut ini:

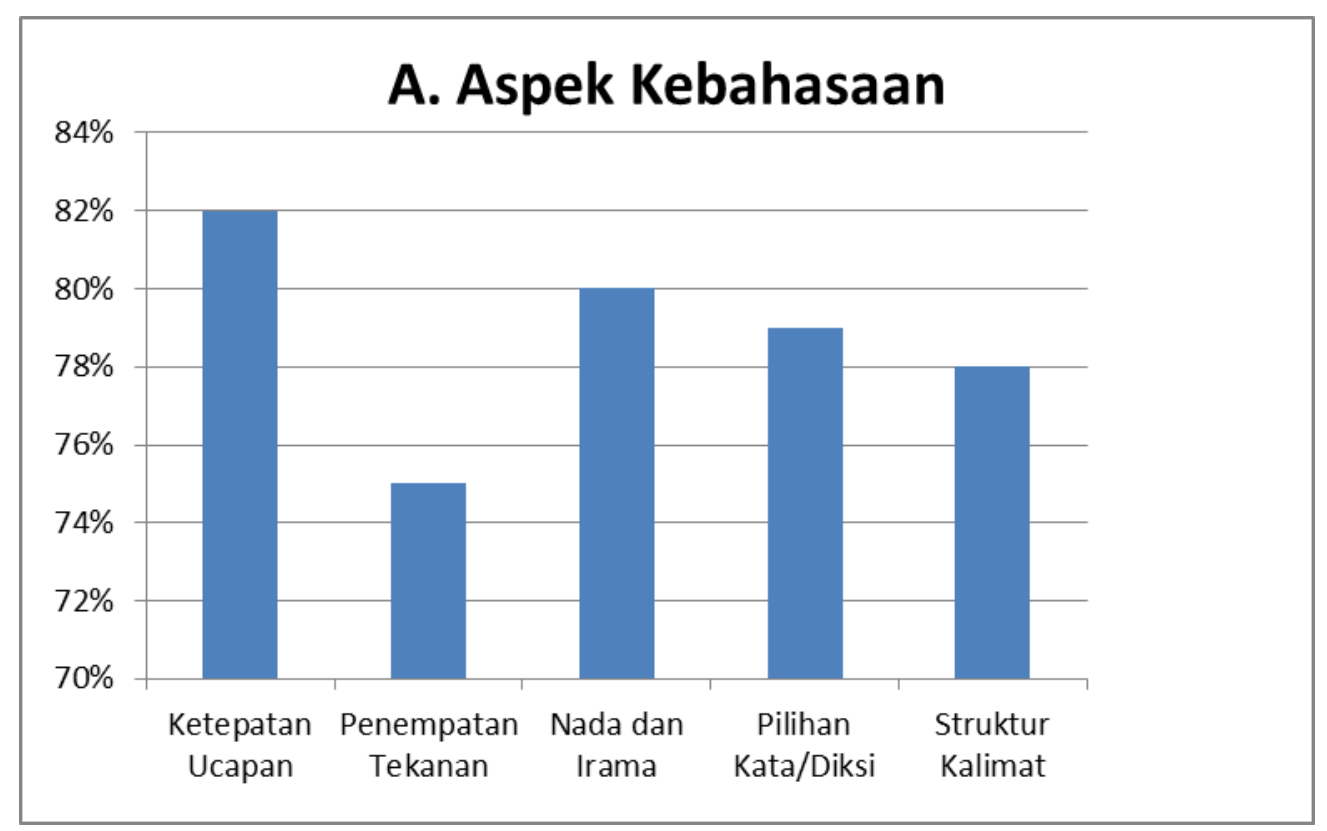

Gambar I. Diagram Presentase Kemampuan Berpidato dari Aspek Kebahasaan

Tabel. 3 Hasil Presentase Kategori Kemampuan Berpidato dari Aspek Kebahasaan

\begin{tabular}{|c|l|c|c|}
\hline No & \multicolumn{1}{|c|}{ Kriteria } & Hasil Presentase & Kategori \\
\hline 1 & Ketepatan Ucapan & $82 \%$ & Baik \\
\hline 2 & Penempatan Tekanan & $75 \%$ & Baik \\
\hline 3 & Nada dan Irama & $80 \%$ & Baik \\
\hline 4 & Pilihan Kata/Diksi & $79 \%$ & Baik \\
\hline 5 & Struktur Kalimat & $78 \%$ & Baik \\
\hline & RATA-RATA & $\mathbf{7 8 , 8 \%}$ & Baik \\
\hline
\end{tabular}

Berdasarkan diagram di atas dapat dilihat bahwa, secara keseluruhan kemampuan berpidato dengan metode memotiter mahasiswa dari aspek kebahasaan bergategori baik. 
Adapun dengan uraian sebagai berikut: ketepatan ucapan memiliki nilai rata-rata $82 \%$, penempatan tekanan memiliki nilai rata-rata $75 \%$, nada dan irama memiliki nilai rata-rata $80 \%$, pilihan kata/diksi memiliki nilai rata-rata 79\%, dan struktur kalimat memiliki nilai ratarata $78 \%$.

Dari uraian diagaram tersebut diketahui bahwa, kemampuan berpidato dengan metode memoriter dari aspek kebahasaan skor yang paling tinggi yaitu dari segi ketepatan ucapan yaitu sebanyak $82 \%$ dengan kategori baik, dan skor yang paling rendah yaitu dari segi penempatan tekanan dengan nilai $75 \%$ juga dengan kategori baik.

Jadi, secara keseluruhan dapat disimpulkan bahwa, kemampuan berpidato dengan metode memoriter mahasiswa Semester I Tahun Akademik 2016/2017 Sekolah Tinggi Agama Islam Negeri Syaikh Abdurrahman Siddik Bangka Belitung dari aspek kebahasaan berkategori baik dengan nilai rata-rata yaitu 78,8\%.

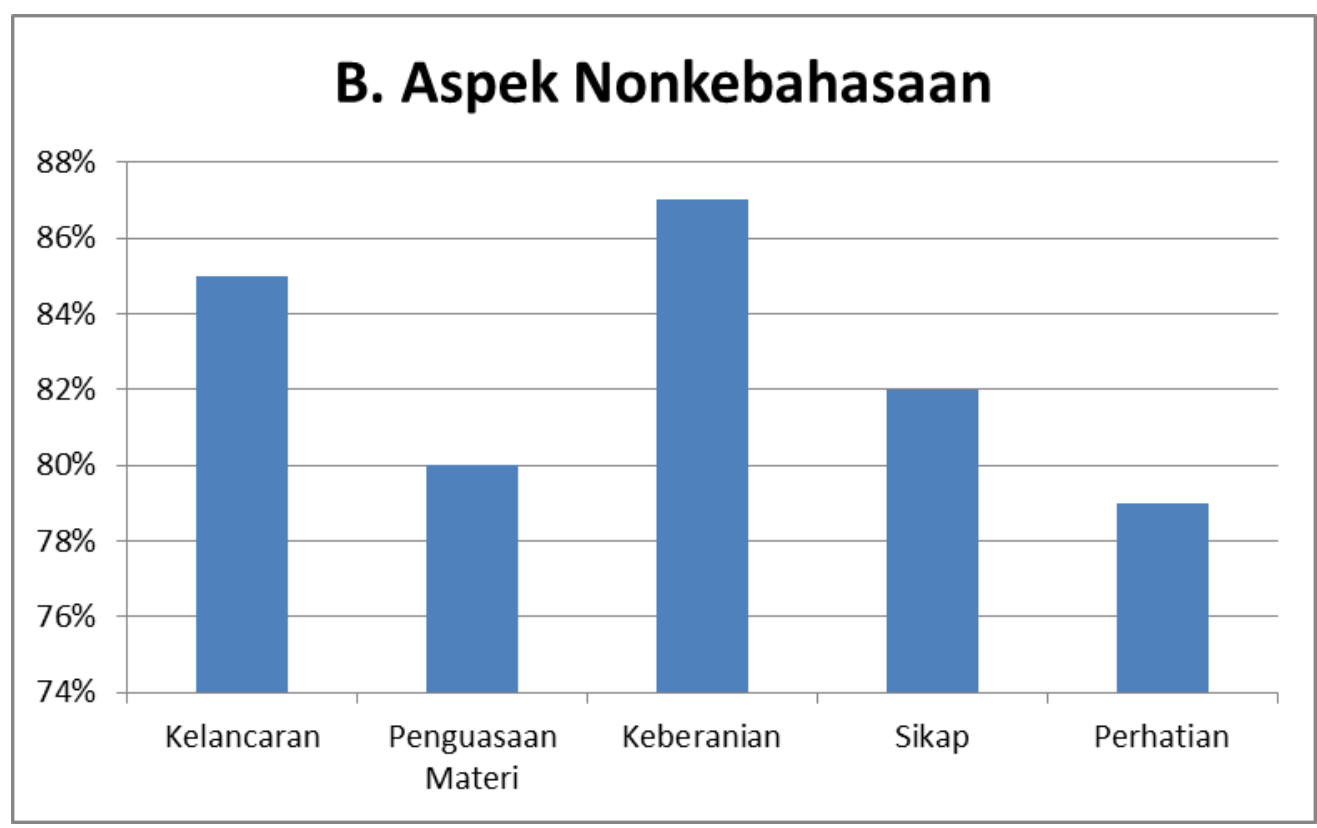

Gambar 2. Diagram Presentase Kemampuan Berpidato dari Aspek Nonkebahasaan

Tabel. 4 Hasil Presentase Kategori Kemampuan Berpidato dari Aspek Nonkebahasaan

\begin{tabular}{|c|l|c|c|}
\hline No & \multicolumn{1}{|c|}{ Kriteria } & Hasil Presentase & Kategori \\
\hline 1 & Kelancaran & $85 \%$ & Baik \\
\hline 2 & Penguasaan Materi & $80 \%$ & Baik \\
\hline 3 & Keberanian & $87 \%$ & Sangat Baik \\
\hline 4 & Sikap & $82 \%$ & Baik \\
\hline
\end{tabular}




\begin{tabular}{|c|l|c|c|}
\hline 5 & Perhatian & $79 \%$ & Baik \\
\hline & RATA-RATA & $\mathbf{8 2 , 6 \%}$ & Baik \\
\hline
\end{tabular}

Berdasarkan diagram di atas dapat dilihat bahwa, secara keseluruhan kemampuan berpidato dengan metode memoriter mahasiswa dari aspek nonkebahasaan bergategori baik. Adapun dengan uraian sebagai berikut: kelancaran memiliki nilai rata-rata $85 \%$, penguasaan materi memiliki nilai rata-rata $80 \%$, keberanian memiliki nilai rata-rata $87 \%$, sikap memiliki nilai rata-rata $82 \%$, dan perhatian memiliki nilai rata-rata $79 \%$.

Dari uraian diagaram tersebut diketahui bahwa dari aspek nonkebahasaan skor yang paling tinggi yaitu dari segi keberanian yaitu sebanyak $87 \%$ yang mencapai kategori sangat baik, dan skor yang paling rendah yaitu dari segi perhatian dengan nilai rata-rata $75 \%$ dengan kategori baik.

Jadi secara keseluruhan dapat disimpulkan bahwa, kemampuan berpidato dengan metode memoriter mahasiswa Semester I Tahun Akademik 2016/2017 Sekolah Tinggi Agama Islam Negeri Syaikh Abdurrahman Siddik Bangka Belitung dari aspek nonkebahasaan berkategori baik dengan nilai rata-rata yaitu $82,6 \%$.

Tabel. 4 Hasil Presentase Kategori Kemampuan Berpidato

\begin{tabular}{|c|l|c|c|}
\hline No & \multicolumn{1}{|c|}{ Aspek } & Hasil Presentase & Kategori \\
\hline 1 & Kebahasaan & $78,8 \%$ & Baik \\
\hline 2 & Nonkebahasaaan & $82,6 \%$ & Baik \\
\hline & RATA-RATA & $\mathbf{8 0 , 7 \%}$ & Baik \\
\hline
\end{tabular}

Dari penjelasan kedua aspek tersebut, yaitu aspek kebahasaan dan aspek nonkebahasaan maka dapat dikatakan bahwa aspek nonkebahasaan sangat mendominasi pemerolehan kemampuan berpidato mahasiswa dengan metode memoriter, yaitu dengan selisih nilai rata-rata 3,8\%. Jadi dapat disimpulkan secara keseluruhan, kemampuan berpidato dengan metode manuskrip mahasiswa semester I Tahun Akademik 2016/2017 Sekolah Tinggi Agama Islam Negeri Syaikh Abdurrahman Siddik Bangka Belitung berkategori baik, dengan nilai rata-rata $80,7 \%$. Hal ini dapat dilihat dari tabel 4 di atas. 


\section{SIMPULAN DAN SARAN}

Berdasarkan hasil penelitian, maka dapat disimpulkan bahwa skor rata-rata kemampuan berpidato dengan menggunakan metode memoriter dilihat dari aspek kebahasaan mendapatkan kategori baik dengan nilai rata-rata 78,8\%. Sama halnya dengan skor rata-rata kemampuan berpidato dengan menggunakan metode memoriter dilihat dari aspek nonkebahasaan juga mendapatkan kategori baik dengan nilai rata-rata 82,6\%.

Jadi secara keseluruhan dapat disimpulkan bahwa kemampuan berpidato dengan metode memoriter mahasiswa Semester I Tahun Akademik 2016/2017 Sekolah Tinggi Agama Islam Negeri Syaikh Abdurrahman Siddik Bangka Belitung berkategori baik, dengan nilai rata-rata $80,7 \%$.

Untuk penelitian lebih lanjut tentang kemampuan berpidato, dapat dilakukan dengan menggunakan metode berpidato yang lain seperti metode impromtu, metode manuskrip, atau metode ekstemporan. 


\section{DAFTAR PUSTAKA}

Arifin, E.Z, Tasai. Cermat Berbahasa Indonesia. 2008. Jakarta: Akademi Pressindo

Arsjad, M.G dan Mukti. 1988. Pembinaan Kemampuan Berbicara Bahasa Indonesia. Jakarta: Bina Aksara.

Bahar, Putra. 2010. Seni Pidato 7 Langkah Sukses Membawakan Pidato. Tangerang: Sunshine Book.

Gentasri, Anwar. Teknik dan Seni Berpidato. 2003. Jakarta: Rineka Cipta

Iskandarwassid dan Dadang Sunendar. 2008. Strategi Pembelajaran Bahasa. Bandung: Remaja Rosdakarya.

Jalaluddin, Rakhmat. 2011. Retorika Modern (Pendekatan Praktis). Bandung: Remaja Rosdakarya.

Roekhan dan Martutik. 1991. Evaluasi Pengajaran Bahasa Indonesia. Malang: YA3 Malang. Safari. 1997. Pengujian dan Penilaian Bahasa dan Sastra Indonesia. Jakarta: PT Kartanegara. Sugiyono. 2009. Metode Penelitian Kuantitatif, Kualitatif, R\&D. Bandung: CV Alfabeta

Tarigan, Henry Guntur. 2008. Berbicara sebagai Suatu Keterampilan Berbahasa. Bandung: Angkasa.

Wangi, Putri Pandan. 2010. Bukan Pidato Biasa. Klaten: One Books. 